OPEN ACCESS

Edited by:

Vasile I. Parvulescu,

University of Bucharest, Romania

Reviewed by:

Valeria Conte,

University of Rome Tor Vergata, Italy Konstantinos Triantafyllidis,

Aristotle University of

Thessaloniki, Greece

*Correspondence:

Roger A. Sheldon

roger.sheldon@wits.ac.za

Specialty section:

This article was submitted to

Green and Sustainable Chemistry,

a section of the journal

Frontiers in Chemistry

Received: 18 December 2019

Accepted: 13 February 2020

Published: 28 February 2020

Citation:

Sheldon RA (2020) Catalytic

Oxidations in a Bio-Based Economy.

Front. Chem. 8:132.

doi: 10.3389/fchem.2020.00132

\section{Catalytic Oxidations in a Bio-Based Economy}

\author{
Roger A. Sheldon ${ }^{1,2 *}$ \\ ${ }^{1}$ School of Chemistry, Molecular Sciences Institute, University of the Witwatersrand, Johannesburg, South Africa, \\ ${ }^{2}$ Department of Biotechnology, Delft University of Technology, Delft, Netherlands
}

The role of bio- and chemo-catalytic aerobic oxidations in the production of commodity chemicals in a bio-refinery is reviewed. The situation is fundamentally different to that in a petrochemicals refinery where the feedstocks are gaseous or liquid hydrocarbons that are oxidized at elevated temperatures in the vapor or liquid phase under solvent-free conditions. In contrast, the feedstocks in a biorefinery are carbohydrates that are water soluble solids and their conversion will largely involve aerobic oxidations of hydroxyl functional groups in water as the solvent under relatively mild conditions of temperature and pressure. This will require the development and use of cost-effective and environmentally attractive processes using both chemo- and biocatalytic methods for alcohols and polyols.

Keywords: bio-based economy, biomass, biocatalysis, catalytic oxidation, alcohol oxidases, carbohydrates, waste valorization

\section{INTRODUCTION}

One of the grand challenges of the twenty-first century is the implementation of the transition from an unsustainable economy based on fossil resources-oil, coal, and natural gas-to a sustainable, carbon-neutral economy based on the use of renewable biomass. This switch to a so-called bio-based economy is urgently required in order to mitigate global warming caused by increasing carbon dioxide emissions to the atmosphere. First generation (1G) renewable raw materials, exemplified by corn starch, sugar cane, and sugar beet, are not perceived as sustainable options in the long term as their utilization involves, directly, or indirectly, competition with food production. In contrast, the use of second generation $(2 \mathrm{G})$ renewable biomass, in the form of waste polysaccharides, such as lignocellulose (Liguori and Faraco, 2016; Zhang et al., 2017) and pectin, from agricultural and forestry residues and food supply chain waste (Dahiya et al., 2018), is perceived as a sustainable long term option for producing biofuels and commodity chemicals (Sheldon, 2014, 2016, 2018; Horváth et al., 2017). Looking further afield, third generation (3G) aquatic biomass, such as micro- and macro-algae and cyanobacteria, has additional advantages (John et al., 2011; Al Abdallah et al., 2016; Shuba and Kifle, 2018). For example, there is no requirement for arable land and fresh water for their production and they have much higher growth rates than terrestrial plants. On the other hand, there are substantial technical problems associated with their production and conversion which, in the short term, represent a significant hurdle to be overcome for commercial viability. 


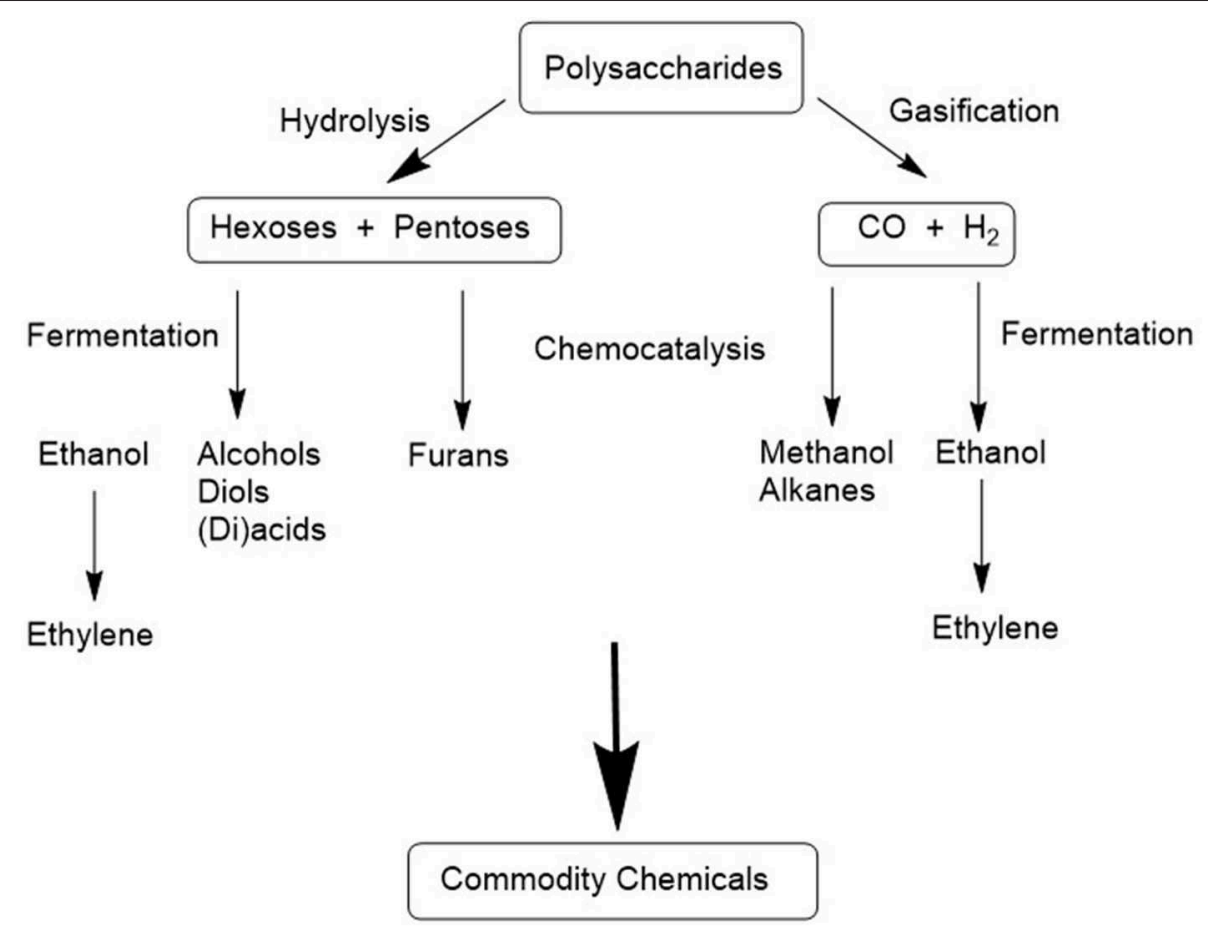

FIGURE 1 | Conversion of polysaccharides to biofuels and commodity chemicals in a biorefinery.

\section{CARBOHYDRATES TO COMMODITY CHEMICALS IN A BIOREFINERY}

In a petrochemical refinery the basic chemicals are lower olefins (ethylene, propylene, and butenes) and aromatics (BTX: benzene, toluene, and xylenes), together with carbon monoxide and hydrogen (syn gas). The hydrocarbons are gases or hydrophobic liquids. They are converted with petrochemical catalytic technologies, particularly catalytic oxidation with dioxygen, to a variety of commodity chemicals, usually in solvent-free systems. In contrast, the basic chemicals in a biorefinery will be $\mathrm{C}_{6}$ and $\mathrm{C}_{5}$ sugars produced by hydrolysis of polysaccharide feedstocks, and/or syn gas produced by their gasification. The carbohydrates are hydrophilic, water soluble solids. Several scenarios can be envisaged for further conversion to commodity chemicals (Figure 1):

(i) Syn gas could be converted to commodity chemicals by applying existing catalytic technologies used in petrochemical refineries or by fermentation (Phillips et al., 2017; Asimakopoulos et al., 2018).

(ii) Monosaccharides such as glucose could be converted to a variety of lower alcohols, diols, carboxylic acids, and dicarboxylic acids by fermentation. Indeed, fermentation is already the commercially most viable route to many of these products with lactic acid, 1,3-propane diol and 1,4-butane diol as prominent examples.

(iii) Bioethanol, produced as a carbon neutral fuel, could be converted to ethylene and a variety of other products using established technologies (see Figure 1), including catalytic aerobic oxidations.

(iv) Chemo- or bio-catalytic conversion of monosaccharides, such as glucose, to commodity chemicals will require in many cases removal of oxygen, by hydrogenolysis and/or dehydration. Catalytic oxidations in a biorefinery involve oxidation of alcoholic $\mathrm{OH}$ groups in monosaccharides, or even the polysaccharide precursors, or their downstream products and further oxidation of the resulting carbonyl compounds.

\section{CATALYTIC OXIDATIONS}

A key reaction in organic synthesis is the oxidation of primary and secondary alcohols to give the corresponding aldehydes or carboxylic acids and ketones, respectively. Traditionally these transformations were performed with stoichiometric quantities of inorganic oxidants, notably chromium (VI) compounds such as the Jones reagent $\left(\mathrm{CrO}_{3}\right.$ and sulfuric acid). However, such procedures are not atom efficient and lead to the formation of copious amounts of toxic, chromium-containing waste, i.e., high $\mathrm{E}$ factors and problematic waste disposal issues. Consequently, in the last two decades such methods have been increasingly replaced by atom efficient catalytic alternatives involving dioxygen or hydrogen peroxide as the terminal oxidant.

Interestingly, the history of catalytic oxidations of carbohydrates (Arts et al., 1997) predates the oxidations of lower olefins and aromatics that form the basis of the 


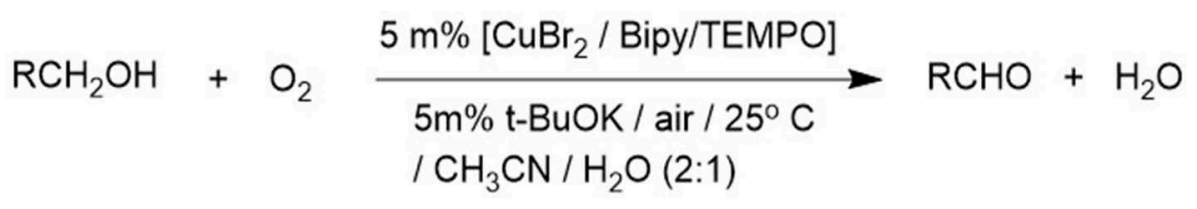

Alcohol
Benzyl alcohol
1-Phenylethanol
Geraniol
Octan-1-ol
Octan-2-ol
Benzyl alcohol +
1-phenylethanol

Time (h) Conversion (\%)

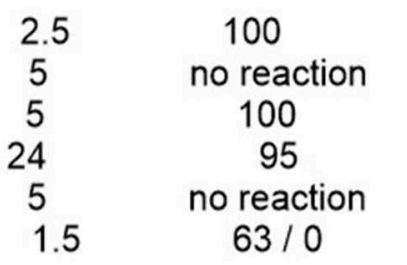

FIGURE 2 | Aerobic oxidation of primary alcohols catalyzed by Cu/TEMPO.

petrochemical industry. The aerobic oxidation of mannose over a platinum black catalyst, for example, dates from 1861 (von Gorup-Besanez, 1861) and many supported noble metal catalyzed aerobic oxidations of carbohydrates were developed in the first half of the last century. At the turn of the century, we developed an aqueous biphasic system for the aerobic oxidation of primary and secondary alcohols to the corresponding aldehydes and ketones, respectively, in a solvent free system using a water-soluble palladium complex of bathophenanthroline (ten Brink et al., 2000). This system could also be effective in the aerobic oxidation of water soluble alcohols, including carbohydrates. Indeed, there are many examples of the aerobic oxidation of alcohols catalyzed by precious metals such as palladium, platinum and gold (Stahl, 2004; Parmaggiani and Cardona, 2012). However, in the context of the conversion of carbohydrates to large volume, low-priced commodity chemicals, precious metals such as palladium have the disadvantage that the future availability of these scarce, "endangered elements" at cost-effective prices is rather unpredictable. Indeed, in contrast to most materials, their price tends to increase with increasing usage. Another disadvantage of noble metal catalyzed oxidations is their functional group intolerance. First row, more earth abundant metals tend to be more functional group tolerant.

Consequently, alternative methods have been developed that use "earth abundant" metals, such as copper and iron, as catalysts. One method with broad applications in the selective oxidation of primary alcohols to aldehydes, even in the presence of secondary alcohols, involves the combination of a $\mathrm{Cu}$ (II)bipyridine (Cu-bpy) complex with a base, such as potassium hydroxide, a stable nitroxyl radical, exemplified by 2,2,6,6tetramethyl-1-piperidine-N-oxyl (TEMPO) and its derivatives, at ambient temperature with air in aqueous acetonitrile (Figure 2; Gamez et al., 2003; Sheldon and Arends, 2004; Marais and Swarts, 2019). The generally accepted mechanism involves as the key, rate determining step, abstraction of a hydrogen atom from an alkoxide ligand by a coordinated nitroxyl radical analogous to that involved in the aerobic oxidation of primary alcohols catalyzed by the copper-dependent oxidase, galactose oxidase (Dijksman et al., 2003). An improved procedure, using Cu(I) salts with TEMPO and bipy in combination with $\mathrm{N}$-methylimidazole as a base in acetonitrile as solvent was subsequently described by Stahl and coworkers (Hoover and Stahl, 2011). Furthermore, extensive mechanistic studies confirmed the copper-centered galactose oxidase-like mechanism for these systems (Geißlmeir et al., 2005; Hoover et al., 2013).

The lack of reactivity of secondary alcohols was attributed to steric hindrance in the abstraction of an $\alpha$-hydrogen atom from a coordinated alkoxide by a coordinated TEMPO ligand. Consequently, the use of sterically less hindered nitroxyl radicals such as AZADO and ABNO, respectively, in combination with $\mathrm{Cu}(\mathrm{I})$ complexes, were developed by the groups of Iwabuchi (Shibuya et al., 2006, 2011; Iwabuchi, 2013) and Stahl (Steves and Stahl, 2013), for the aerobic oxidation of secondary alcohols (Figure 3), including sterically demanding alcohols such as menthol and a variety of unprotected amino alcohols (Sasano et al., 2014).

More recently, $\mathrm{Ma}$ and coworkers reported the use of an $\mathrm{Fe}$ (III)/4-hydroxyTEMPO/NaCl combination as a catalyst for the aerobic oxidation of both primary and secondary alcohols (Jiang et al., 2016, 2019). Other metals, including manganese, cobalt and vanadium, have also been used in combination with nitroxyl radicals (Cao et al., 2014) Transition metal free nitroxyl systems have also been described, usually involving nitrogen dioxide as the active co-catalyst. The commercially most attractive source of the $\mathrm{NO}_{2}$ cocatalyst is nitric acid (Kuang et al., 2010). For example, nitric acid or $\mathrm{NaNO}_{2}$ or a mixture of both was used, in combination with $\mathrm{ABNO}$ or keto-ABNO, for the selective aerobic oxidation of secondary alcohols (Figure 4; Lauber and Stahl, 2013). Interestingly, the combination of nitric acid and $\mathrm{NaNO}_{2}$ catalyzes the aerobic oxidation of alcohols even in the absence of a stable nitroxyl radical. The reaction involves an alkyl nitrite intermediate which decomposes to the carbonyl 


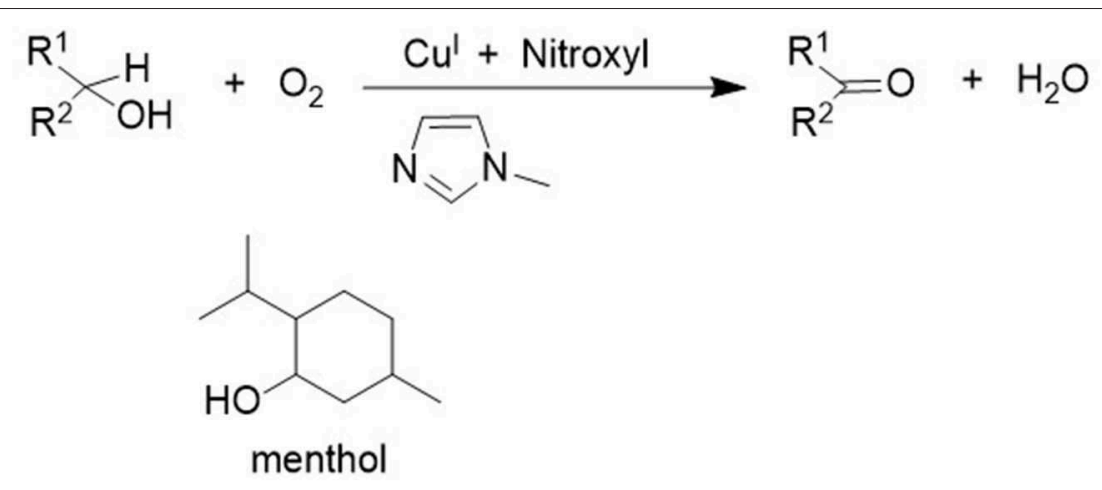

\section{Nitroxyl:}

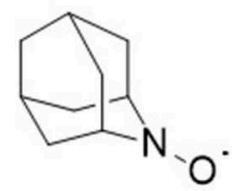

AZADO

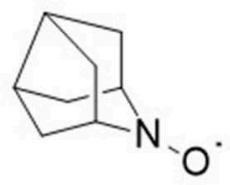

nor-AZADO

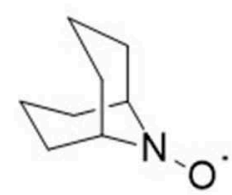

ABNO

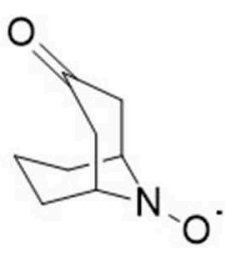

keto-ABNO

FIGURE 3 | Catalytic aerobic oxidation of secondary alcohols with $\mathrm{Cu}$ (I)/nitroxyl catalysts.

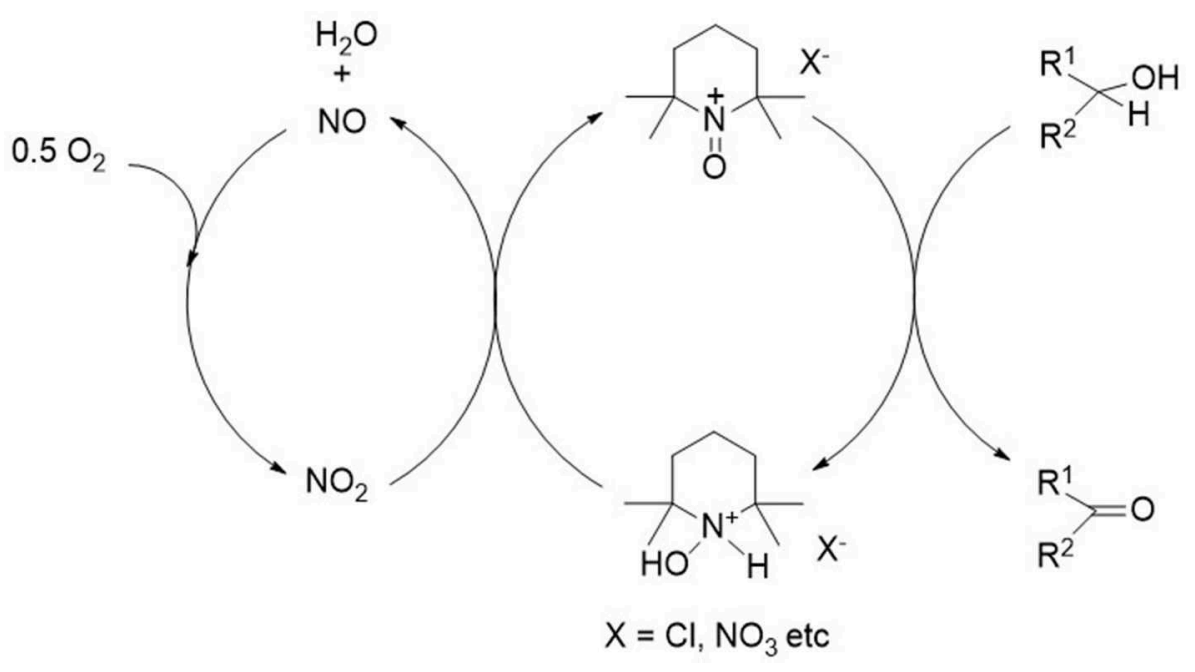

FIGURE 4 | Nitric acid catalyzed aerobic oxidation of alcohols.

compound and $\mathrm{HNO}$ which is reoxidized by dioxygen (Aellig et al., 2011). Unfortunately, the greenhouse gas, nitrous oxide $\left(\mathrm{N}_{2} \mathrm{O}\right)$, can be irreversibly formed as a byproduct.

\section{CATALYTIC OXIDATIONS IN A BIO-BASED ECONOMY}

Although these various nitroxyl radical-based catalysts have been widely used in the aerobic oxidations of alcohols they have generally involved relatively simple primary and secondary alcohols in organic solvents, sometimes mixed with water. This was done with the development of green syntheses of, for example, active pharmaceutical ingredients (APIs) and flavors and fragrances, in mind. However, in a bio-based economy it is of interest to use these methodologies in the selective oxidation of renewable carbohydrates or key alcohols, diols, and polyols derived from them, and this involves in many cases aqueous solutions of solid substrates. 
<smiles>O[C@H]1CO[C@@H]2[C@@H](O)CO[C@H]12</smiles><smiles>O=C1CO[C@H]2C(=O)CO[C@H]12</smiles>

isosorbide<smiles>C[C@H]([AlH2])[C@H](N)CN</smiles>

Catalyst:

A AA-TEMPO $/ \mathrm{HNO}_{3}$ in $\mathrm{HOAC}$

AA-TEMPO

B Laccase/TEMPO in HOAC

FIGURE 5 | Aerobic oxidation of isosorbide to the corresponding diketone. (A) AA-TEMPO/HNO 3 in HOAc. (B) Laccase/Tempo in HOAc.

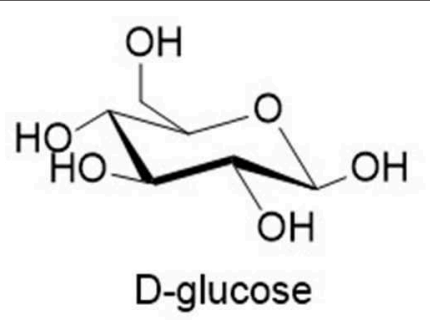<smiles>CCCCCCCCCCO</smiles><smiles>O[C@H]1CO[C@@H]2[C@@H](O)CO[C@H]12</smiles>

isosorbide

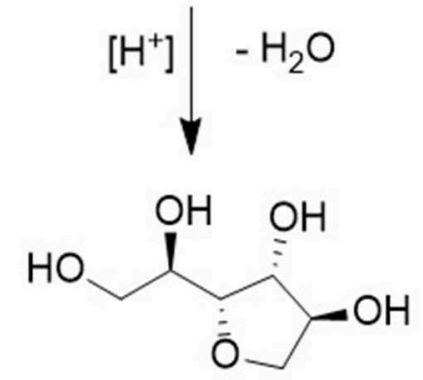

sorbitan 
Water has both advantages and limitations as a solvent for aerobic oxidations. For example, oxidations with oxygen are much safer as there is no formation of explosive mixtures of oxygen with volatile organic solvents in the gas phase. In a typical process oxygen is supplied by bubbling air through the solution. However, the transfer of oxygen from the gas to the liquid phase is notoriously slow owing to its low solubility in water under typical operating conditions $\left(0.268 \mathrm{mM}\right.$ at $25^{\circ} \mathrm{C}$ and 1 bar air) which limits the maximum space time yield to 200 $\mathrm{mmol} / \mathrm{L} / \mathrm{h}$ (Pedersen et al., 2015). This problem was alleviated in the $\mathrm{Cu} / \mathrm{TEMPO}$ system by using air-microbubble techniques to facilitate gas absorption into the liquid phase (Mase et al., 2011). Alternatively, the rates of enzymatic aerobic oxidations were increased by a factor of 100 in continuous flow operation compared to the conventional batch operation (Chapman et al., 2018; Hone and Kappe, 2019). Another disadvantage of water as a solvent is that its relatively high heat capacity, compared to volatile organic solvents, translates to high energy costs for its removal by distillation.

A pertinent example, from the viewpoint of the biobased economy, is the use of acetylamino-TEMPO (AATEMPO) together with nitric acid as the cocatalyst for the aerobic oxidation of primary and secondary alcohols to the corresponding aldehydes and ketones, respectively, in acetic acid or water as the solvent (Dingerdissen et al., 2011). The method was particularly useful for the oxidation of the key biomassderived diol, isosorbide, to the corresponding diketone (Figure 5; Klasovsky et al., 2015). This is particularly surprising because of the low reactivity of the shielded endo $\mathrm{OH}$ group in isosorbide.

Isosorbide is a commercially interesting platform chemical produced by hydrogenation of glucose to sorbitol followed by dehydration (Figure 6). It has interesting features as an industrial monomer based on its rigidity, chirality, and non-toxicity (Fenouillot et al., 2010). For example, reaction with dicarboxylic acids (or esters) affords polyesters. Alternatively, oxidation to the corresponding diketones, followed by reductive amination, affords the corresponding bis-primary amine (Figure 5) which can be converted to polyamides by reaction with dicarboxylic acids (esters).

\section{BIOCATALYSIS IN AQUA: THE NATURAL SOLUTION}

As was noted elsewhere, biocatalysis is green and sustainable (Hollmann et al., 2011; Sheldon and Woodley, 2018), conforming to 10 of the 12 principles of green chemistry, and the catalyst is non-toxic, biocompatible and biodegradable. Moreover, enzymatic reactions are generally performed in water, a particularly suitable medium for conversions of polysaccharides in a bio-based economy. Furthermore, carbohydrates tend to be ideal substrates and generally have a stabilizing effect on enzymes. In contrast with precious metal catalysts, the long term availability and price stability of enzymes is assured since they are produced from inexpensive, readily available biomass. Moreover, industrial scale oxidations employing precious metal catalysts often involve a costly purification step to remove traces of the metal in the product. In contrast, no costly removal of trace amounts of enzymes are needed in enzymatic oxidations and any enzyme ending up in aqueous effluent undergoes facile biodegradation.

\section{Laccase/Nitroxyl Radical Combinations}

Laccases (EC 1.10. 3.2) are a diverse group of extracellular, copper-dependent oxidases. They are produced, for example,

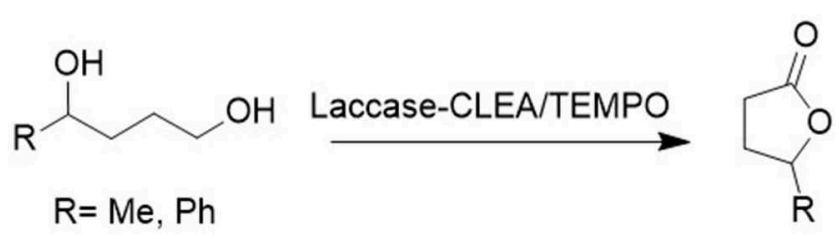

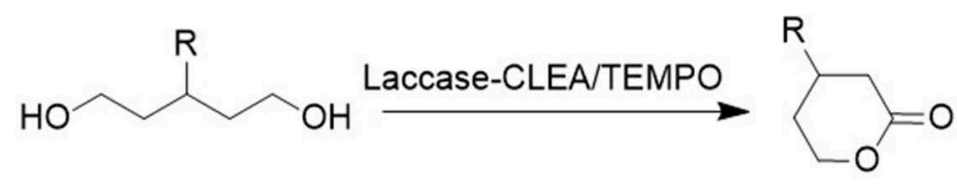<smiles>OC1CC(O)C(O)C(O)C(O)C1O</smiles>

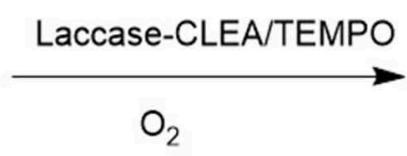

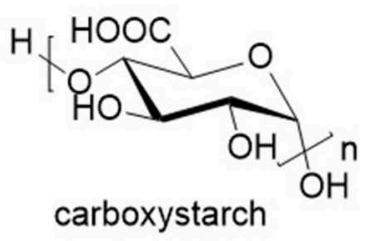

FIGURE 7 | Laccase/TEMPO catalyzed oxidation of diols and polyols. 
by white rot fungi, and play a key role in the delignification of lignocellulose in vivo (Rochefort et al., 2004). There is considerable commercial interest in the use of laccases in the pulp and paper industry and in waste water remediation in general (Gasser et al., 2014; Singh et al., 2018; Unuofin et al., 2019). They have broad substrate specificity and use dioxygen to oxidize a wide variety of, inter alia, phenols and aromatic amines in vivo. In combination with so-called mediators, notably TEMPO, they are able oxidize alcohols as was first shown by Fabbrini et al. (2001). These reactions involve one-electron oxidation of the TEMPO by the laccase to give the oxoammonium cation which is the active oxidant (Arends et al., 2006a). The reduced form of laccase is then reoxidized by dioxygen.

The laccase/TEMPO system was shown to catalyze the aerobic oxidation of primary and secondary aliphatic alcohols and 10 mol\% was sufficient to give good conversions and excellent selectivities (Arends et al., 2006b). Interestingly, Ying and coworkers (Zhu et al., 2014) obtained superior results with 5 mol\% laccase/AZADO, especially in the aerobic oxidation of complex and highly functionalized alcohols. Suicide inactivation is a problem with laccases since at high substrate conversions the oxoammonium cation can oxidize reactive groups in the protein or in the associated glycosyl moieties on the periphery of the enzyme (laccases are glycosylated enzymes). The stability of laccases under the reaction conditions can be significantly increased by immobilization as cross-linked enzyme aggregates (CLEAs) (Matijosyte et al., 2010).

The laccase/TEMPO system also catalyzed the aerobic oxidation of the renewable diol, isosorbide to the corresponding diketone (see section Catalytic Oxidations and Figure 5B) in $>99 \%$ yield (Gross et al., 2014). Similarly, 1,4 and 1,5-diols were oxidized to the corresponding lactones (Figure 7, DiazRodriguez et al., 2012) and immobilization of the laccase as crosslinked enzyme aggregates (CLEAs) enabled multiple recycling (Sheldon et al., 2013).

\section{Copper and Flavin Dependent Alcohol Oxidases}

As shown in Figure 8, there are two types of alcohol oxidases: $\mathrm{Cu}$-dependent and flavin adenine dinucleotide (FAD). Both generate an equivalent of hydrogen peroxide as the coproduct and catalase is added to decompose it back to oxygen and water. Alternatively, catalase can be used to generate oxygen in situ. A major shortcoming of wild-type oxidases is their substrate specificity. For example, galactose oxidase (GOase) and glucose

\section{FAD-dependent alcohol oxidase}
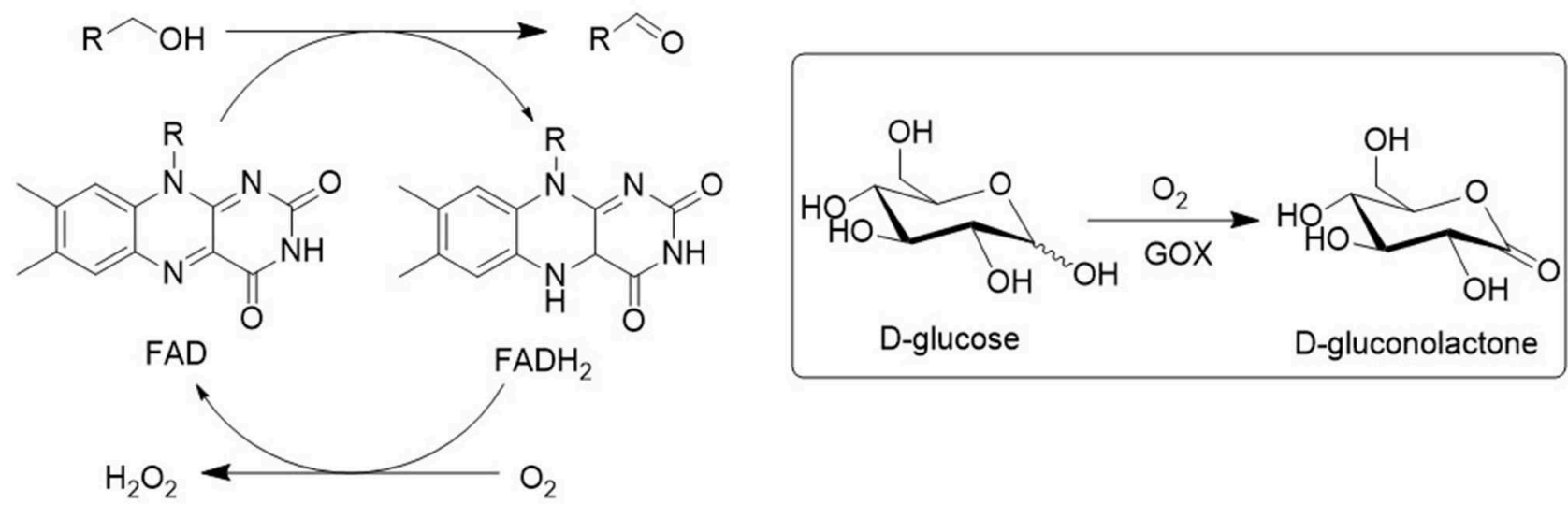

\section{$\underline{\text { Cu-dependent alcohol oxidase }}$}
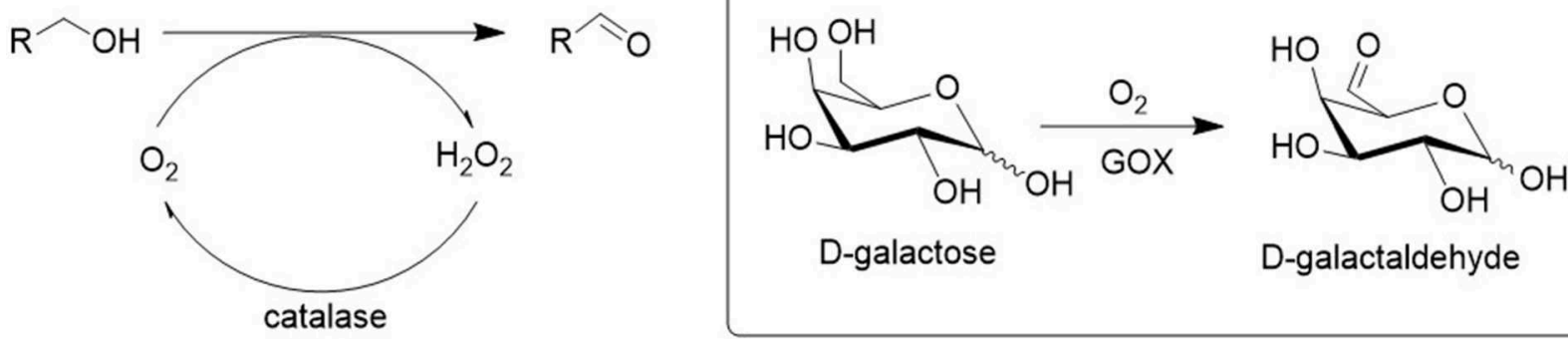

FIGURE 8 | Types of alcohol oxidases. 


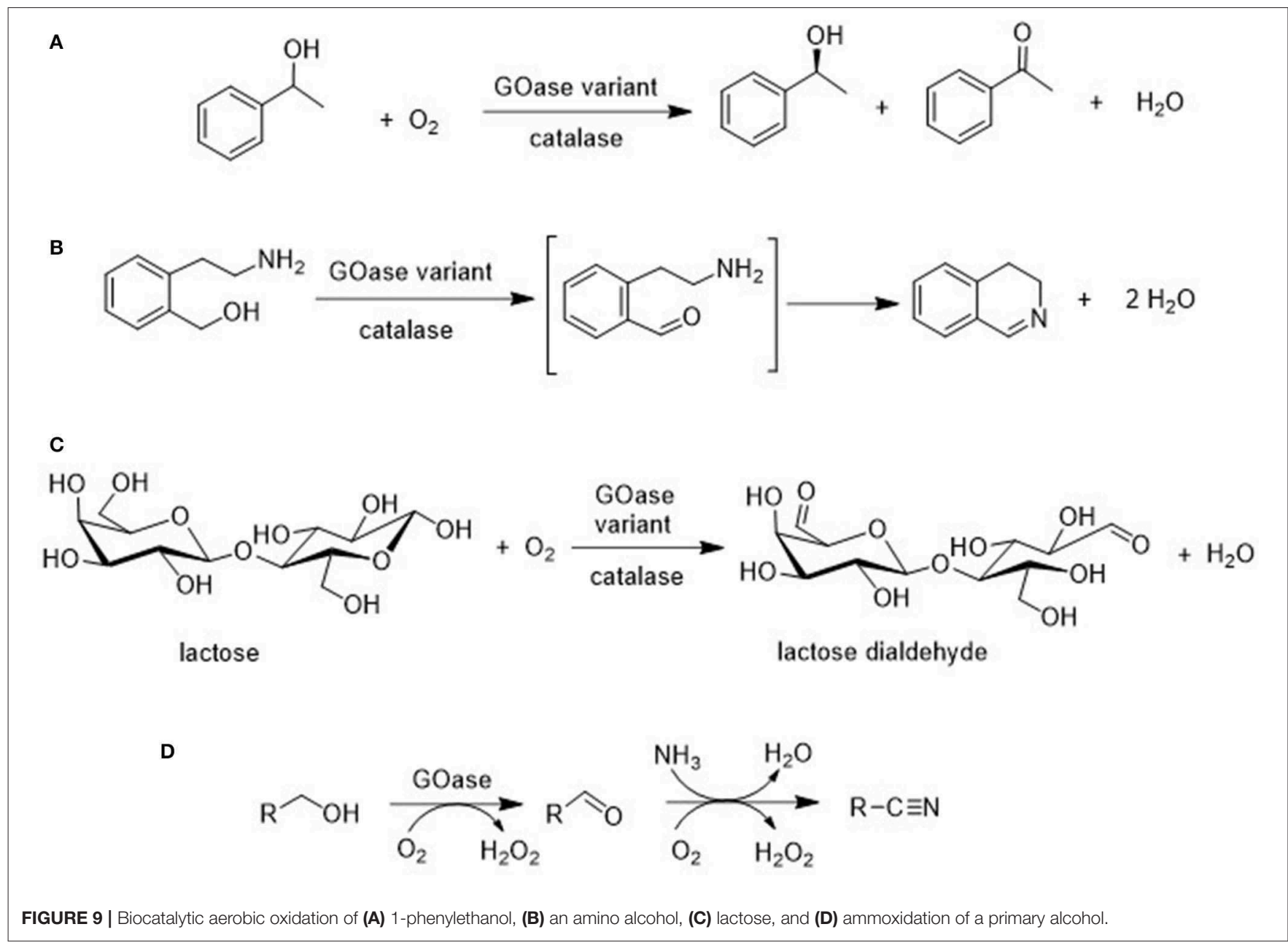

oxidase (GOX) and are very specific for galactose and glucose, respectively. Indeed, these enzymes have evolved in vivo to be very efficient in converting their natural substrate. However, in order to be useful in organic synthesis they need to be active and selective with a variety of alcohol substrates, particularly highly functionalized alcohols. Fortunately, this can be achieved with protein engineering using in vitro evolution.

For example, Turner and coworkers used directed evolution techniques to produce GOase variants that catalyze the oxidation of secondary alcohols (Figure 9A; Escaletters and Turner, 2008) and amino alcohols (Herter et al., 2015; Figure 9B). Similarly, a GOase variant catalyzed the aerobic oxidation of lactose, a disaccharide formed as a waste stream (whey) in cheese manufacture, to form the dialdehyde (Figure 9C; Cosgrove et al., 2019). The latter is of interest as a raw material for polymers. Interestingly, a GOase variant was also shown to catalyze the synthesis of nitriles by ammoxidation of primary alcohols (Figure 9D; Vilim et al., 2018).

Structure directed evolution was also used to develop variants of the FAD-dependent choline oxidase that catalyze the aerobic oxidation of a broad range of primary alcohols to the corresponding aldehydes (Figure 10; Heath et al., 2019). Similarly, FAD-dependent HMF oxidase was engineered to effectively catalyze all three oxidation steps in the conversion of HMF to FDCA (see later).

Another reaction of industrial interest is the aerobic oxidation of glucose to glucaric acid. A hypothetical process involving two steps with a mixture of GOX and a GOase variant which is able to accept gluconolactone as a substrate is shown in Figure 11. Alternatively, it can be produced by aerobic oxidation of glucuronic acid, a building block derived from (waste) pectin (see section Acid-Catalyzed Dehydration of Carbohydrates to Furan Derivatives). Glucaric acid is of interest as an industrial monomer in itself ( $\mathrm{Wu}$ et al., 2019) and can also be hydrogenated to adipic acid, the raw material for Nylon 6.

\section{Alcohol Dehydrogenases}

Alcohol dehydrogenases (ADHs) catalyze the oxidation of alcohols by utilizing a nicotinamide cofactor which has to be regenerated in situ using an excess of a co-substrate (Kroutil et al., 2004a; Weckbecker et al., 2010). Alternatively, NAD(P)H oxidase (NOx) can be employed to catalyze reoxidation of the cofactor by oxygen (Kroutil et al., 2004b; Zhang et al., 2016). Yet another possibility is to couple the oxidation step with a reduction step, 

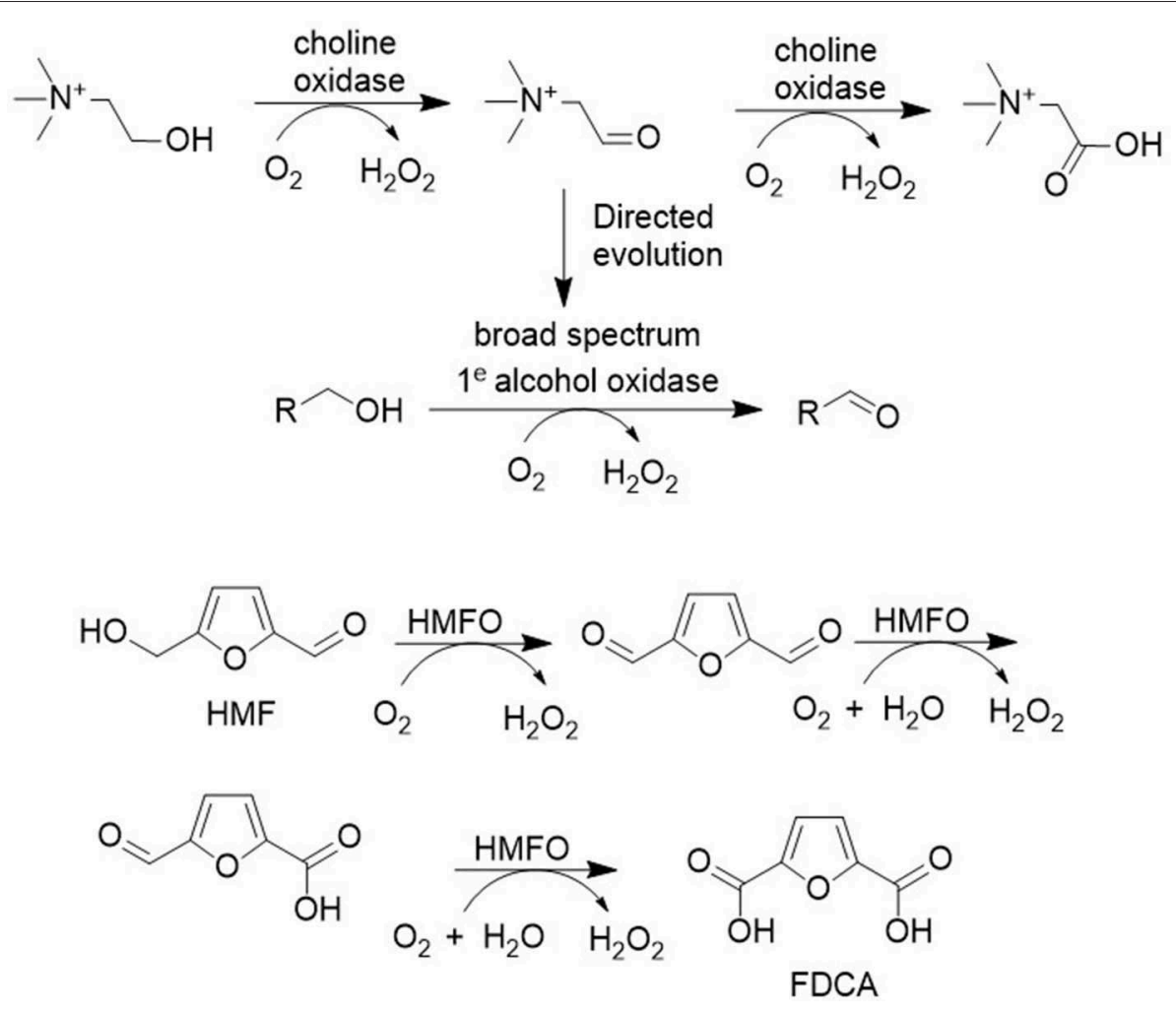

FIGURE 10 | Aerobic oxidations catalyzed by FAD-dependent alcohol oxidase variants.

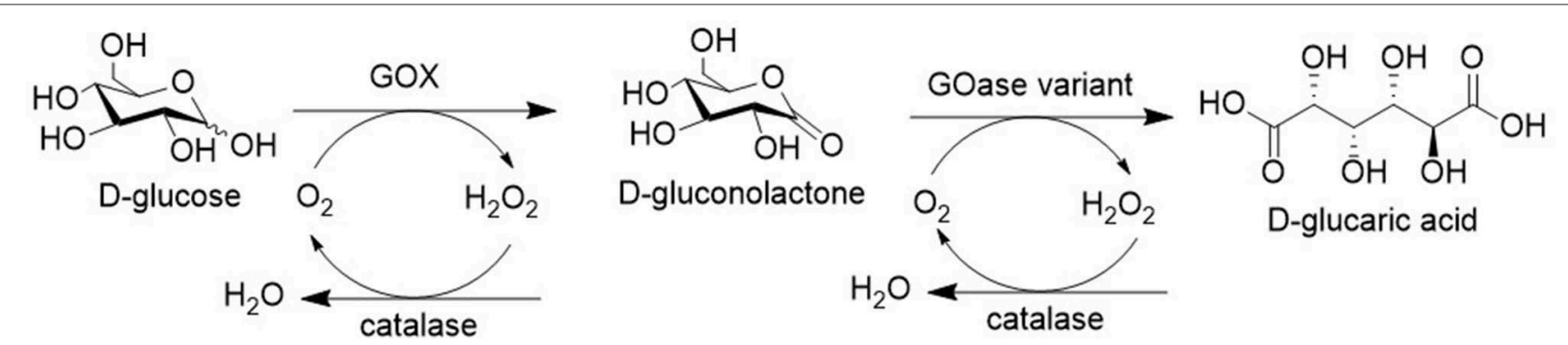

FIGURE 11 | Hypothetical biocatalytic oxidation of glucose to glucaric acid.

to afford an overall redox neutral process by employing socalled hydrogen borrowing, a concept which itself was borrowed from chemocatalysis literature (Hamid et al., 2007). For example, combination of an $\mathrm{ADH}$ with an amine dehydrogenase $(\mathrm{AmDH})$ affords a redox-neutral conversion of a racemic alcohol to a single enantiomer of the corresponding amine (Figure 12; Mutti et al., 2015). Ironically, it requires the use of an aselective $\mathrm{ADH}$ (Thompson and Turner, 2017) because it has to catalyze the oxidation of both alcohol enantiomers, which is not a simple task as most ADHs are highly enantioselective. The overall efficiency of the process, which constitutes a conversion of an $\mathrm{OH}$ to an $\mathrm{NH}_{2}$ group, was improved by co-immobilization of the $\mathrm{ADH}$ and AmDH (Böhmer et al., 2018). When the alcohol, or polyol, is readily available this would be an industrially attractive way to produce the corresponding (poly)amine. A pertinent example is the conversion of isosorbide to the diamine discussed in section Catalytic Oxidations.

\section{Direct Oxidation of Polysaccharides}

It is also of commercial interest to oxidize polysaccharides, e.g., starch and cellulose, directly to the corresponding polycarboxylic acids. Carboxystarch, for example, has potential applications as a biodegradable water super absorbent. Polysaccharides can be readily oxidized using $\mathrm{NaOCl}$ as the stoichiometric oxidant and TEMPO or derivatives as the catalyst (Ponedel'kina et al., 2010). However, for a commercially and environmentally attractive process it should preferably use oxygen as the stoichiometric oxidant. The laccase/TEMPO system (see above) catalyzes the 


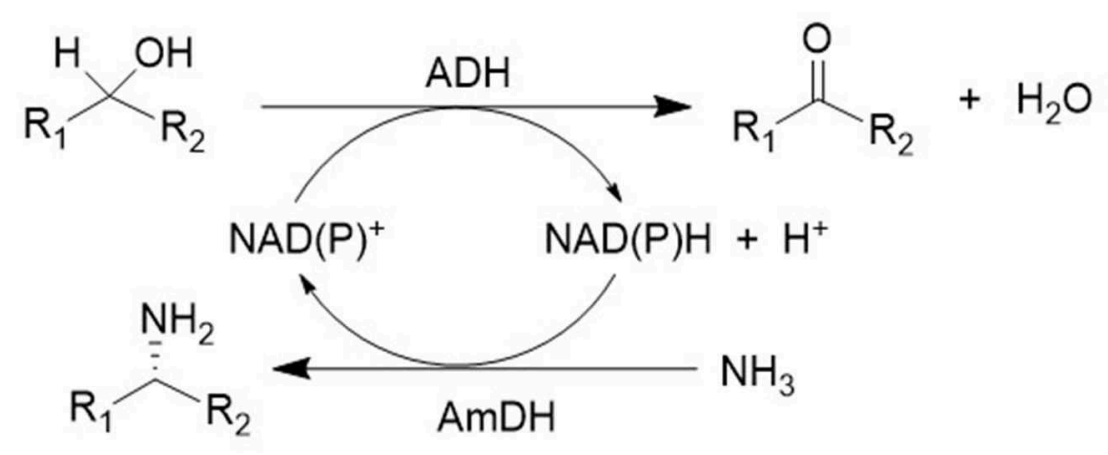

\section{Overall:}

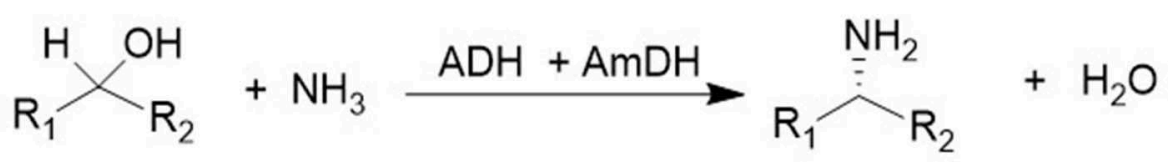

FIGURE 12 | Enzymatic conversion of an alcohol to an amine.
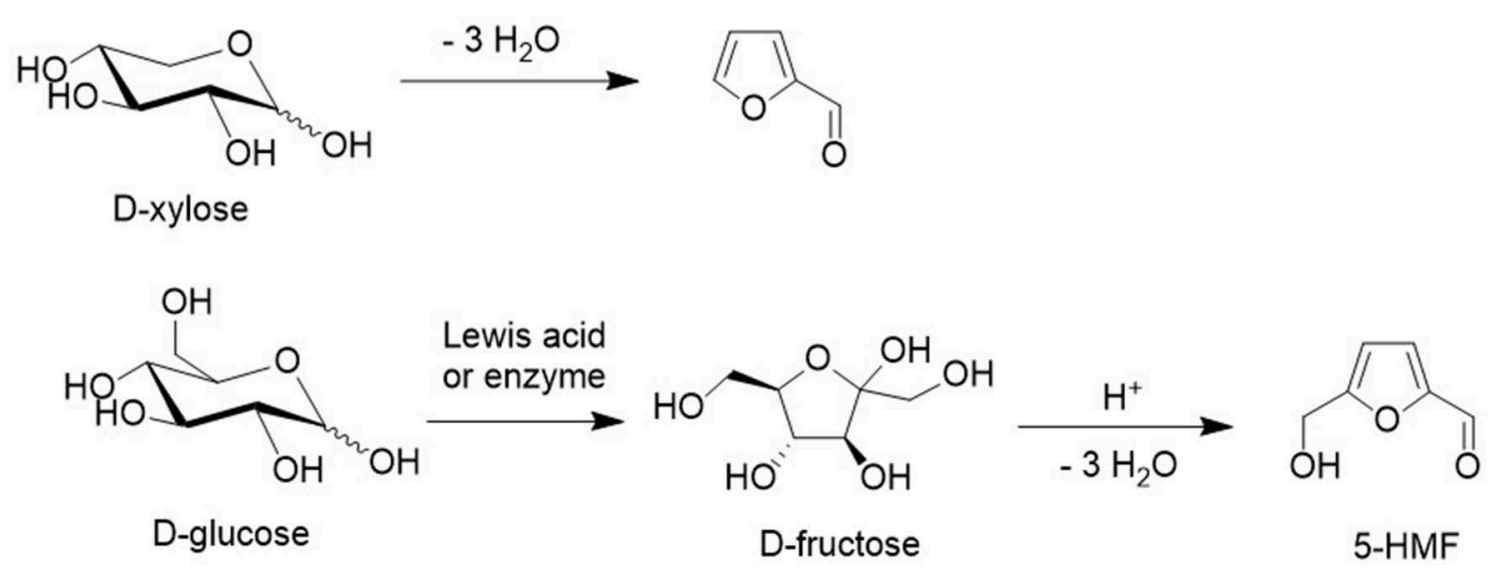

FIGURE 13 | Acid catalyzed dehydration of xylose and glucose.

aerobic oxidation of the primary alcohol moieties in starch affording carboxystarch (Viikari et al., 1999) but the relatively high enzyme costs, owing to its instability under the oxidizing reaction conditions, form an obstacle to commercialization. The stability was improved by immobilization as a cross-linked enzyme aggregate (CLEA) (Matijosyte et al., 2010).

\section{ACID-CATALYZED DEHYDRATION OF CARBOHYDRATES TO FURAN DERIVATIVES}

Acid catalyzed dehydration of pentoses and hexoses produces furfural and 5-hydroxymethylfurfural (HMF) (Tong et al., 2010), respectively. Furfural is an important commodity chemical (Lange et al., 2012) and HMF has the potential to become one (van Putten et al., 2013; Kucherov et al., 2018). Initial isomerization of D-glucose to D-fructose is followed by acid catalyzed dehydration (Figure 13) but in yields that are not conducive to commercial viability owing to the limited stability of HMF in the acidic reaction medium (Wang et al., 2017). However, according to a recent report HMF can be obtained in $95 \%$ yield by conducting the reaction with D-fructose under continuous flow conditions (Galaverna et al., 2018).

Polyethylene furandicarboxylate (PEF), which was developed by Avantium ${ }^{1}$ is produced from furan-2,5-dicarboxylic acid

\footnotetext{
$\overline{{ }^{1} \text { https://www.avantium.com/blog/pef-the-polymer-for-the-future/ }}$
} 

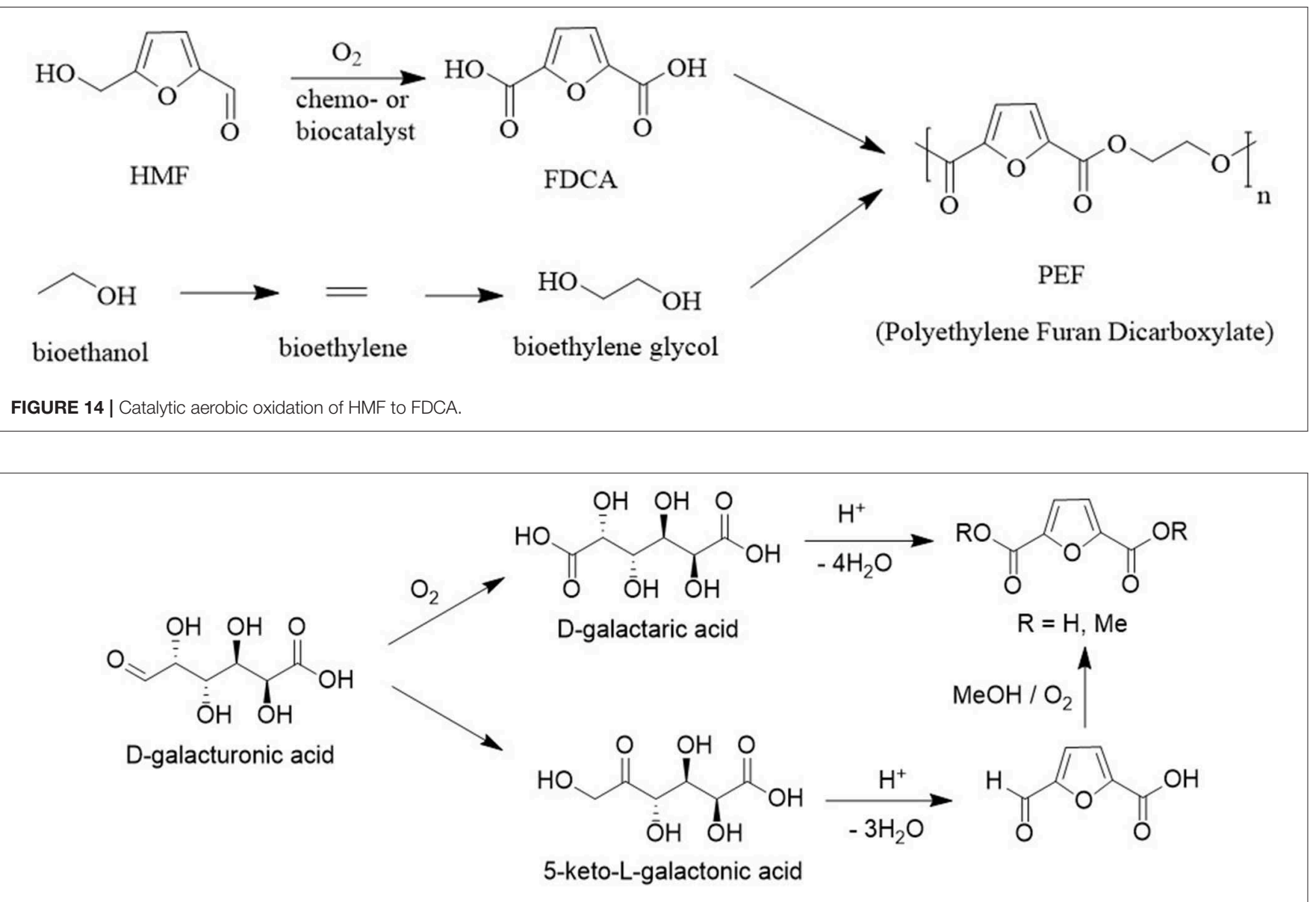

FIGURE 15 | Alternative routes to FDCA.

(FDCA) and ethylene glycol It is seen as a renewable alternative for fossil-based polyethylene terephthalate (PET). In addition to reducing $\mathrm{CO}_{2}$ emissions, $\mathrm{PEF}$ has superior mechanical, thermal, and gas barrier properties to PET. The key raw material, FDCA, can be produced in excellent yields by aerobic oxidation of HMF using supported precious metal catalysts (Liu et al., 2015; Zhang and Deng, 2015; Zheng et al., 2017; Motagamwala et al., 2018) or an engineered flavin-dependent alcohol oxidase (Dijkman et al., 2015) or whole cell biocatalysts (Koopman et al., 2010) in aqueous media (Figure 14).

FDCA can also be produced from uronic acids present in various agricultural residues. D-galacturonic acid, for example, is available in large quantities from the pectin in sugar beet pulp (Leijdeckers et al., 2013) and D-glucuronic acid is one of the main constituents of pectin in certain soft- and hardwoods. Aerobic oxidation of uronic acids over gold catalysts (van Es et al., 2013) affords the corresponding aldaric acids that can subsequently be dehydrated to FDCA (Figure 15; Miller et al., 2017). Alternatively, uronic acids can be isomerized to the corresponding 5-keto aldonic acids which can be converted to FDCA dimethyl ester by acid catalyzed cyclodehydration to the methyl ester of 5-formyl-2-furoic acid in methanol followed by $\mathrm{Au} / \mathrm{C}$ catalyzed aerobic oxidation (van der Klis et al., 2017).
Finally, we note that this review is focused on the conversion of the carbohydrate fractions of feedstocks to commodity chemicals in a biorefinery. In practice, for commercial viability both the carbohydrate and the lignin fractions will be converted to both commodity chemicals and biofuels and this will involve both chemo- and biocatalytic methods in water (Rinaldi et al., 2016; Bugg et al., 2019).

\section{CONCLUSIONS AND PROSPECTS}

Remarkable progress has been made in the last two decades in the development of green and sustainable catalytic methodologies for the aerobic oxidations of primary and secondary alcohols to aldehydes and ketones, respectively. However, a cursory perusal of the literature reveals that we have hardly scratched the surface with regard to the application of such catalytic methodologies to the valorization of bio-based feedstocks and key platform chemicals in biorefineries. Recent developments in the engineering of oxidative enzymes, such as copper- and flavindependent alcohol oxidases, using directed evolution techniques, strongly suggest that industrially viable methods for catalytic oxidations relevant to a bio-based economy will be forthcoming in the near future. 
One could say that glucose is the new ethylene, and possibly propylene and butenes all rolled into one. In the words of Primo Levi: "It is the destiny of wine to be drunk and it is the destiny of glucose to be oxidized."

\section{REFERENCES}

Aellig, C., Girard, C., and Hermans, I. (2011). Aerobic alcohol oxidations mediated by nitric acid. Angew. Chem. Int. Ed. 50, 12355-12360. doi: 10.1002/anie. 201105620

Al Abdallah, Q. A., Nixon, B. T., and Fortwender, J. R. (2016). The enzymatic conversion of major algal and cyanobacterial carbohydrates to bioethanol. Front. Energy Res. 4:36. doi: 10.3389/fenrg.2016.00036

Arends, I. W. C. E., Li, Y. X., Ausan, R., and Sheldon, R. A. (2006a). Comparison of TEMPO and its derivatives as mediators in laccase catalysed oxidation of alcohols. Tetrahedron 62, 6659-6665. doi: 10.1016/j.tet.2005.12.076

Arends, I. W. C. E., Li, Y. X., and Sheldon, R. A. (2006b). Stabilities and rates in the laccase/TEMPO-catalyzed oxidation of alcohols. Biocat. Biotransform. 24, 443-448. doi: 10.1080/10242420601040683

Arts, S. J. H. F., Mombarg, E. J. M., van Bekkum, H., and Sheldon, R. A. (1997). Hydrogen peroxide and oxygen in catalytic oxidation of carbohydrates and related compounds. Synthesis 597-613. doi: 10.1055/s-1997-1406

Asimakopoulos, K., Gavala, H. N., and Skiadis, I. V. (2018). Reactor systems for syngas fermentation processes: A review. Chem. Eng. J. 348, 732-744. doi: $10.1016 /$ j.cej.2018.05.003

Böhmer, W., Kraus, T., and Mutti, F. (2018). Hydrogen-borrowing alcohol bioamination with coimmobilized dehydrogenases. ChemCatChem. 10, 731-735. doi: $10.1002 /$ cctc. 201701366

Bugg, T. D. H., Williamson, J. J., and Rashid, G. M. M. (2019). Bacterial enzymes for lignin depolymerisation: new catalysts for generation of renewable chemicals from biomass. Curr. Opin. Chem. Biol. 55, 26-33. doi: 10.1016/j.cbpa.2019.11.007

Cao, Q., Dornan, L. M., Rogan, L., Hughes, N. L., and Muldoon, M. J. (2014). Aerobic oxidation catalysis with stable radicals. Chem. Commun. 50, 4524-4543. doi: 10.1039/C3CC47081D

Chapman, M. R., Cosgrove, S. C., Turner, N. J., Kapur, N., and Blacker, N. J. (2018). Highly productive oxidative biocatalysis in continuous flow by enhancing the aqueous equilibrium solubility of oxygen. Angew. Chem. Int. Ed. 57,10535-10539. doi: 10.1002/anie.201803675

Cosgrove, S. C., Mattey, A. P., Riese, S., Chapman, M. R., Birmingham, W. R., Blacker, J. A., et al. (2019). Biocatalytic oxidation in continuous flow for the generation of carbohydrate dialdehydes. ACS Catal. 9, 11658-11662. doi: $10.1021 /$ acscatal.9b04819

Dahiya, S., Kumar, A. N., Sravan, J. S., Chatterjee, S., and Sarkar, O. (2018). Food waste biorefinery: sustainable strategy for circular economy. Bioresour. Technol. 248, 2-12. doi: 10.1016/j.biortech.2017.07.176

Diaz-Rodriguez, A., Lavandera, I., Kanbak-Aksu, S., Sheldon, R. A., Gotor, V., and Gotor-Fernandez, V. (2012). From diols to lactones under aerobic conditions using a laccase/TEMPO catalytic system in aqueous medium. Adv. Synth. Catal. 354, 3405-3408. doi: 10.1002/adsc.201200892

Dijkman, W. P., Binda, C., Fraaije, M. W., and Mattevi, A. (2015). Structurebased enzyme tailoring of 5-hydroxymethylfurfural oxidase. ACS Catalysis 5, 1833-1839. doi: 10.1021/acscatal.5b00031

Dijksman, A., Arends, I. W. C. E., and Sheldon, R. A. (2003). Cu(II)-Nitroxyl radicals as catalytic galactose oxidase mimics. Org. Biomol. Chem. 1, 3232-3237. doi: 10.1039/b305941c

Dingerdissen, U., Pfeffer, J., Tacke, T., Haas, T., Schmidt, H., Klasovsky, F., et al. (2011). Method for Producing Aldehydes and Ketones From Primary and Secondary Alcohols. US 2011/0251399 A1. Essen: Evonik Degussa GmbH.

Escaletters, F., and Turner, N. J. (2008). Directed evolution of galactose oxidase: generation of enantioselective secondary alcohol oxidases. ChemBioChem. 9, 857-860. doi: 10.1002/cbic.200700689

Fabbrini, M., Galli, C., Gentili, P., and Machitella, D. (2001). An oxidation of alcohols by oxygen with the enzyme laccase and mediation by TEMPO. Tetrahedron Lett. 42, 7551-7553. doi: 10.1016/S0040-4039(01)01463-0

\section{AUTHOR CONTRIBUTIONS}

The author confirms being the sole contributor of this work and has approved it for publication.

Fenouillot, F., Rousseau, A., Colomines, G., Saint-Loup, R., and Pascault, J. P. (2010). Polymers from renewable 1,4:3,6-dianhydrohexitols (isosorbide, isomannide and isoidide): a review. Progr. Polym. Sci. 35, 578-622. doi: 10.1016/j.progpolymsci.2009.10.001

Galaverna, R., Breitkreitz, M. C., and Pastre, J. C. (2018). Conversion of D-fructose to 5-(hydroxymethyl)furfural: evaluating batch and continuous flow conditions by design of experiments and in-line FTIR monitoring. ACS Sust. Chem. Eng. 6, 4220-4230. doi: 10.1021/acssuschemeng.7b04643

Gamez, P., Arends, I. W. C. E., Reedijk, J., and Sheldon, R. A. (2003). Copper(II)- catalysed oxidation of primary alcohols. Chem. Commun. 2414-2415. doi: 10.1039/b308668b

Gasser, C. A., Ammann, E. M., Shahgaldian, P., and Corvini, P. F. X. (2014). Laccases to take on the challenge of emerging organic contaminants in wastewater. Appl. Microbiol. Biotechnol. 98, 9931-9952. doi: 10.1007/s00253-014-6177-6

Geißlmeir, D., Jary, W. G., and Falk, H. (2005). The TEMPO/copper catalyzed oxidation of primary alcohols to aldehydes using oxygen as stoichiometric oxidant. Monatsh Chem. 136, 1591-1599. doi: 10.1007/s00706-005-0349-0

Gross, J., Tauber, K., Fuchs, M., Schmidt, N. G., Rajagopalan, A., Faber, K., et al. (2014). Aerobic oxidation of isosorbide and isomannide employing TEMPO/Laccase. Green Chem. 16, 2117-2121. doi: 10.1039/C3GC41855C

Hamid, M. H. S. A., Slatford, P. A., and Williams, J. M. J. (2007). Borrowing hydrogen in the activation of alcohols. Adv. Synth. Catal. 349, 1555-1575. doi: $10.1002 /$ adsc. 200600638

Heath, R. S., Birmingham, W. R., Thompson, M. P., Taglieber, A., Daviet, L., and Turner, N. J. (2019). An engineered alcohol oxidase for the oxidation of primary alcohols. ChemBioChem. 20, 276-281. doi: 10.1002/cbic.201800556

Herter, S., McKenna, S. M., Frazer, A. R., Lehmk $\alpha$ hler, S., Carnell, A. J., and Turner, N. J. (2015). Galactose oxidase variants for the oxidation of amino alcohols in enzyme cascade synthesis. ChemCatChem. 7, 2313-2317. doi: $10.1002 /$ cctc. 201500218

Hollmann, F., Arends, I. W. C. E., Buehler, K., Schallmey, A., and Bühler, B. (2011). Enzyme-mediated oxidations for the chemist. Green Chem. 13, 226-265. doi: 10.1039/C0GC00595A

Hone, C. A., and Kappe, C. O. (2019). The use of molecular oxygen for liquid phase aerobic oxidations in continuous flow. Top. Curr. Chem. 377:2. doi: 10.1007/s41061-019-0233-8

Hoover, J. M., Ryland, B. L., and Stahl, S. S. (2013). Copper/TEMPO- catalyzed aerobic oxidation of alcohols: mechanistic assessment of different catalyst systems. ACS Catal. 3, 2599-2605. doi: 10.1021/cs400689a

Hoover, J. M., and Stahl, S. S. (2011). Highly practical copper(I)/TEMPO catalyst system for chemoselective aerobic oxidation of primary alcohols. J Am Chem Soc. 133, 16901-16910. doi: 10.1021/ja206230h

Horváth, I. T., Cséfalvay, E., Mika, L. T., and Debreczeni, M. (2017). Sustainability metrics for biomass-based carbon chemicals. ACS Sustainable Chem. Eng. 5, 2734-2740. doi: 10.1021/acssuschemeng.6b03074

Iwabuchi, Y. (2013). Discovery and exploitation of AZADO: the highly active catalyst for alcohol oxidation. Chem. Pharm. Bull. 61, 1197-1213. doi: 10.1248/cpb.c13-00456

Jiang, X., Liu, J., and Ma, S. (2019). Iron-catalyzed aerobic oxidation of alcohols: lower cost and improved selectivity. Org. Proc. Res. Dev. 23, 825-835. doi: 10.1021/acs.oprd.8b00374

Jiang, X., Zhang, J., and Ma, S. (2016). Iron catalysis for room-temperature aerobic oxidation of alcohols to carboxylic acids. J. Am. Chem. Soc. 138, 8344-8347. doi: 10.1021/jacs.6b03948

John, R. P., Anisha, G. S., Nampoothiri, K. M., and Pandey, A. (2011). Micro and macroalgal biomass: a renewable source for bioethanol. Bioresour. Technol. 102, 186-193. doi: 10.1016/j.biortech.2010.06.139

Klasovsky, F., Haas, T., Tacke, T., Pfeffer, J. C., Rimbach, M., Volland, M., et al. (2015). Continuously Operable Method for Producing Carbonyl Compounds by 
Means of a Catalyst Containing a Nitroxyl Radical. US 8,981,159 B2. Essen: Evonik Degussa GmbH.

Koopman, F., Wiercxk, N., de Winde, J. H., and Ruijssenaaars, H. J. (2010). Efficient whole-cell biotransformation of 5-(hydroxymethyl)furfural into FDCA, 2,5-furandicarboxylic acid. Bioresour. Technol. 101, 6291-6296. doi: 10.1016/j.biortech.2010.03.050

Kroutil, W., Mang, H., Edegger, K., and Faber, K. (2004a). Biocatalytic oxidation of primary and secondary alcohols. Adv. Synth. Catal. 346, 125-142. doi: $10.1002 /$ adsc. 200303177

Kroutil, W., Mang, H., Edegger, K., and Faber, K. (2004b). Recent advances in the biocatalytic reduction of ketones and oxidation of sec-alcohols. Curr. Opin. Chem. Biol. 8, 120-126. doi: 10.1016/j.cbpa.2004.02.005

Kuang, Y., Rokubuichi, H., Nabae, Y., Hayakawa, T., and Kakimoto, M. (2010). A nitric acid assisted carbon-catalyzed oxidation system with nitroxide radical cocatalysts as an efficient and green protocol for selective aerobic oxidation of alcohols. Adv. Synth. Catal. 352, 2635-2642. doi: 10.1002/adsc.201000366

Kucherov, F. A., Romashov, L. V., Galkin, K. I., and Ananikov, V. P. (2018). Chemical transformations of biomass-derived C6-furanic platform chemicals for sustainable energy research, materials science and synthetic building blocks. ACS Sust. Chem. Eng. 6, 8064-8092. doi: 10.1021/acssuschemeng.8b00971

Lange, J. P., van der Heide, E., van Buijtenen, J., and Price, R. (2012). Furfural a promising platform for lignocellulosic biofuels. ChemSusChem. 5, 150-166. doi: $10.1002 /$ cssc. 201100648

Lauber, M. B., and Stahl, S. S. (2013). Efficient aerobic oxidation of secondary alcohols at ambient temperature with an $\mathrm{ABNO} / \mathrm{NO}_{x}$ catalyst system. ACS Catal. 3, 2612-2616. doi: 10.1021/cs400746m

Leijdeckers, A. G. M., Bink, J. P. M., Geutjes, S., Schols, H. A., and Gruppen,. H. (2013). Enzymatic saccharification of sugar beet pulp for the production of galacturonic acid and arabinose; a study on the impact of the formation of recalcitrant oligosaccharides. Bioresour. Technol. 128, 518-525. doi: 10.1016/j.biortech.2012.10.126

Liguori, R., and Faraco, V. (2016). Biological processes for advancing lignocellulosic waste biorefinery by advocating circular economy. Bioresour. Technol. 215, 13-20. doi: 10.1016/j.biortech.2016.04.054

Liu, B., Ren, Y., and Zhang, Z. (2015). Aerobic oxidation of 5hydroxymethylfurfural into 2,5-furandicarboxylic acid in water under mild conditions. Green Chem. 17, 1610-1617. doi: 10.1039/C4GC02019G

Marais, L., and Swarts, A. J. (2019). Biomimetic Cu/Nitroxyl catalyst systems for selective alcohol oxidation. Catalysts 9, 1-28. doi: 10.3390/catal9050395

Mase, N., Mizumori, T., and Tatemoto, Y. (2011). Aerobic copper/TEMPOcatalyzed oxidation of primary alcohols to aldehydes using a microbubble strategy to increase gas concentration in liquid phase reactions. Chem. Commun. 47, 2086-2088. doi: 10.1039/c0cc04377j

Matijosyte, I., Arends, I. W. C. E., de Vries, S., and Sheldon, R. A. (2010). Preparation and use of cross-linked enzyme aggregates (CLEAs) of laccases. J. Mol. Catal. B 62, 142-148. doi: 10.1016/j.molcatb.2009.09.019

Miller, D. J., Peereboom,. L., and Wegener, E., Gattinger, M. (2017). Formation of 2,5-Furandicarboxylic Acid From Aldaric Acids. US 9701652 B1 2017. Board of Trustees of Michigan State University.

Motagamwala, A. H., Won, W., Sener, C., Alonso, D. M., Marvelias, C. T., and Dumesic, J. A. (2018). Toward biomass-derived renewable plastics: production of 2,5-furandicarboxylic acid from fructose. Sci Adv. 4, 1-8. doi: 10.1126/sciadv.aap9722

Mutti, F. G., Knaus, T., Scrutton, N. S., Breuer, M., and Turner, N. J. (2015). Conversion of alcohols to enantiopure amines through dual-enzyme hydrogenborrowing cascades. Science 349, 1525-1529. doi: 10.1126/science.aac9283

Parmaggiani, C., and Cardona, F. (2012). Transition metal based catalysts in the aerobic oxidation of alcohols. Green Chem. 14, 547-564. doi: $10.1039 / \mathrm{c} 2 \mathrm{gc} 16344 \mathrm{f}$

Pedersen, A. T., Birmingham, W. R., Rehn, G., Charnock, S. J., Turner, N. J., and Woodley, J. M. (2015). Process requirements of galactose oxidase catalyzed oxidation of alcohols. Org. Proc. Res. Dev. 19, 1580-1589. doi: 10.1021/acs.oprd.5b00278

Phillips, J. R., Huhnke, R. L., and Atiyeh, H. K. (2017). Syngas fermentation: a microbial conversion process of gaseous substrates to various products. Fermentation 3:28. doi: 10.3390/fermentation3020028

Ponedel'kina, I. Y., Khaibrakhmanova, E. A., and Odinokov, V. N. (2010). Nitroxide-catalyzed selective oxidation of alcohols and polysaccharides.
Russ. Chem. Rev. 79, 63-75. doi: 10.1070/RC2010v079n01ABEH0 04074

Rinaldi, R., Jastrzebski, R., Clough, M. T., Ralph, J., Kennema, M., Bruijnincx, P. C. A., and Weckhuysen, B. M. (2016). Paving the way for lignin valorization: recent advances in bioengineering, biorefining and catalysis. Angew. Chem. Int. Ed. 55, 8164-8215. doi: 10.1002/anie.201510351

Rochefort, D., Leech, D., and Bourbonnais,. R. (2004). Electron transfer mediator systems for bleaching of paper pulp. Green Chem. 6, 614-624. doi: $10.1039 / \mathrm{b} 311898 \mathrm{n}$

Sasano, Y., Nagasawa, S., Yamazaki, M., Shibuya, M., Park, J., and Iwabuchi, Y. (2014). Highly chemoselective aerobic oxidation of amino alcohols into amino carbonyl compounds. Angew. Chem. Int. Ed. 53, 3236-3240. doi: 10.1002/anie.201309634

Sheldon, R. A. (2014). Green and sustainable manufacture of chemicals from biomass: state of the art. Green Chem. 16, 950-963. doi: 10.1039/C3GC41935E

Sheldon, R. A. (2016). Green chemistry, catalysis and valorization of waste biomass J. Mol. Catal. A 422, 3-12. doi: 10.1016/j.molcata.2016.01.013

Sheldon, R. A. (2018). The road to biorenewables: carbohydrates to commodity chemicals. ACS Sustain. Chem. Eng. 6, 4464-4480. doi: 10.1021/acssuschemeng.8b00376

Sheldon, R. A., and Arends, I. W. C. E. (2004). Organocatalytic oxidations mediated by nitroxyl radicals Adv. Synth. Catal. 346, 1051-1071. doi: 10.1002/adsc.200404110

Sheldon, R. A., van Pelt, S., Kanbak-Aksu, S., Rasmussen, J., and Janssen, M. H. A. (2013). Cross-linked enzyme aggregates in organic synthesis. Aldrichimica Acta, 46, 81-93.

Sheldon, R. A., and Woodley, J. M. (2018). Role of biocatalysis in sustainability. Chem. Rev.118, 801-838. doi: 10.1021/acs.chemrev.7b00203

Shibuya, M., Osada, Y., Sasano, Y., Tomizawa, M., and Iwabuchi, Y. (2011). Highly efficient, organocatalytic aerobic alcohol oxidation. J. Am. Chem. Soc. 133, 6497-6500. doi: 10.1021/ja110940c

Shibuya, M., Tomizawa, M., Suzuki, I., and Iwabuchi, Y. (2006). 2Azaadamantane $N$-Oxyl (AZADO) and 1-Me-AZADO: highly efficient organocatalysts for oxidation of alcohols. J. Am. Chem. Soc. 128, 8412-8413. doi: $10.1021 /$ ja0620336

Shuba, E. S., and Kifle, D. (2018). Microalgae to biofuels: 'Promising' alternative and renewable energy, review. Renew Sust. Energy Rev. 81, 743-755. doi: 10.1016/j.rser.2017.08.042

Singh, J., Saharan, V., Kumar, S., Gulati, P., and Kapoor, R. K. (2018). Laccase grafted membranes for advanced water filtration systems: a green approach to water purification technology. Crit. Rev. Biotechnol. 38, 883-901. doi: $10.1080 / 07388551.2017 .1417234$

Stahl, S. S. (2004). Selective oxidation of organic compounds by direct dioxygen-coupled turnover. Angew. Chem. Int. Ed. 43, 3400-3420. doi: 10.1002/anie.200300630

Steves, J. E., and Stahl, S. S. (2013). Copper/ABNO catalyzed aerobic alcohol oxidation. Alleviating steric and electronic constraints of $\mathrm{Cu} /$ tempo catalyst systems. J. Am. Chem. Soc. 135, 15742-15745. doi: 10.1021/ja409241h

ten Brink, G. J., Arends, I. C. W. E., and Sheldon, R. A. (2000). Green, catalytic oxidation of alcohols in water. Science 287,1636-1639. doi: $10.1126 /$ science.287.5458.1636

Thompson, M. P., and Turner, N. J. (2017). Two-enzyme hydrogen-borrowing amination of alcohols enabled by a cofactor-switched alcohol dehydrogenase. ChemCatChem. 23, 3833-3836. doi: 10.1002/cctc.201701092

Tong, X., Ma, Y., and Li, Y. (2010). Biomass into chemicals: conversion of sugars to furan derivatives by catalytic processes. Appl. Catal. A 385, 1-13. doi: 10.1016/j.apcata.2010.06.049

Unuofin, J. O., Okoh, A. I., and Nwodo, U. U. (2019). Aptitude of oxidative enzymes for treatment of wastewater pollutants: a laccase perspective. Molecules, 24:2064. doi: 10.3390/molecules24112064

van der Klis, F., van Haveren, J., van Es, D. S., and Bitter, J. H. (2017). Synthesis of furan dicarboxylic acid esters from nonfood feedstocks without concomitant levulinic acid formation. ChemSusChem, 10, 1460-1468. doi: $10.1002 /$ cssc. 201700051

van Es, D. S., van Haveren, J., Raaijmakers, H. W. C., van der Klis, F., and van Engelen, G. P. F. M. (2013). Catalytic Oxidation of Uronic Acids to Aldaric Acids. WO 2013/151428 A1. Wageningen: Stichting Dienst Landbouwkundig Onderzoek. 
van Putten, R. J., van der Waal, J. C., de Jong, E., Rasrendra, C. B., Heeres, H. J., and de Vries, J. G. (2013). Hydroxymethylfurfural, a versatile platform chemical made from renewable resources. Chem. Rev. 113, 1499-1597. doi: $10.1021 / \mathrm{cr} 300182 \mathrm{k}$

Viikari, L., Niku-Paavola, M. I., Buchert, J., Forssell, P. Teleman, A., and Kruus, K. (1999). Method of Producing Oxidized Starch. Helsinki: Valtion Teknillinen Tutkimuskeskus, WO 99/23240.

Vilim, J., Kraus, T., and Mutti, F. (2018). Catalytic Promiscuity of galactose oxidase. a mild synthesis of nitriles from alcohols, air and ammonia. Angew. Chem. Int. Ed. 57, 14240-14244. doi: 10.1002/anie.2018 09411

von Gorup-Besanez, E. F. (1861). Ueber die producte der einwirkung des platinmohrs auf mannit. Ann Chem. 118:257. doi: 10.1002/jlac.18611180302

Wang, J., Xi, J., Xia, Q., Liu, X., and Wang, Y. (2017). Recent advances in heterogeneous catalytic conversion of glucose to 5-hydroxymethylfurfural via green routes. Sci. China Chem. 60, 870-886. doi: 10.1007/s11426-0169035-1

Weckbecker, A., Gröger, H., and Hummel, W. (2010). Regeneration of nicotinamide coenzymes: principles and applications for the synthesis of chiral compounds. Adv. Biochem. Eng. Biotechnol. 120, 195-242. doi: 10.1007/10_2009_55

Wu, Y., Enomoto, Y., Masaki, H., and Iwata, T. (2019). Synthesis of polyamides from sugar derived D-glucaric acid and xylylenediamines. J. Appl. Polym. Sci. 136, 1-6. doi: 10.1002/app.47255

Zhang, J. D., Cui, Z. M., Fan, X. J., Wu, H. L., and Chang, H. H. (2016). Cloning and characterization of two distinct water-forming NADH oxidases from Lactobacillus pentosus for the regeneration of NAD. Bioprocess Biosyst. Eng. 39, 603-611. doi: 10.1007/s00449-016-1542-8

Zhang, Z., and Deng, K. (2015). Recent advances in the catalytic synthesis of 2,5-furandicarboxylic acid and its derivatives. ACS Catal. 5, 6529-6544 doi: 10.1021/acscatal.5b01491

Zhang, Z., Song, J., and Han, B. (2017). Catalytic transformation of lignocellulose into chemicals and fuel products in ionic liquids. Chem. Rev. 117, 6834-6880. doi: 10.1021/acs.chemrev.6b00457

Zheng, L., Zhao, J., Du, Z., Zong, B., and Liu, H. (2017). Efficient aerobic oxidation of 5-hydroxymethylfufural to 2,5-furandicarboxylic acid on Ru/C catalysts. Chem. Sci. China 60, 950-957. doi: 10.1007/s11426-0160489-3

Zhu, C., Zhang, Z., Ding, W., Xie, J., Chen, Y., Wu, J., et al. (2014). A mild and highly efficient laccase-mediator system for aerobic oxidation of alcohols. Green Chem. 16, 1131-1138. doi: 10.1039/C3GC42124D

Conflict of Interest: The author declares that the research was conducted in the absence of any commercial or financial relationships that could be construed as a potential conflict of interest.

Copyright (C) 2020 Sheldon. This is an open-access article distributed under the terms of the Creative Commons Attribution License (CC BY). The use, distribution or reproduction in other forums is permitted, provided the original author $(s)$ and the copyright owner(s) are credited and that the original publication in this journal is cited, in accordance with accepted academic practice. No use, distribution or reproduction is permitted which does not comply with these terms. 